\title{
Rock Mass Reinforcement Systems in Open Pit Excavations in Urban Areas
}

\author{
Ž. Arbanas Civil Engineering Institute of Croatia, University of Rijeka, Croatia \\ M. Grošić Civil Engineering Institute of Croatia, University of Rijeka, Croatia
}

M.S. Kovačević Faculty of Civil Engineering, University of Zagreb, Croatia

\begin{abstract}
In the City of Rijeka, Croatia, in the Kantrida region, the Water Sport Complex for the 2008 European Champion ship is under construction. An excavation for a garage in the north part of the complex is the most geotechnically demanding part of the project. Several existing buildings (a petrol station and an apartment building) and a traffic line to the north are in close proximity to the construction site. Geotechnical conditions at the site are very complex: on the lateral sides of the pit a limestone rock mass outcrops at surface while in the eastern central part of the location there is a ravine filled with deep clayey deposits. The natural surficial terrain has significantly been changed by cut and fills activities. The excavation itself involves a construction pit, varying from $14.50 \mathrm{~m}$ deep on the northern end to $1 \mathrm{~m}$ depth on the southern end, which was designed, based on the results of the detailed geotechnical investigation work performed. The open pit was constructed in several phases, with a retaining wall constructed for the soil layers and reinforcement by bolting and a grid reinforced concrete construction. During the open pit construction, a monitoring system was established. An active design procedure was established which made possible required changes to the rock mass reinforcement system in the cuts. This paper presents the execution of this work, as well as the behaviour of reinforcement systems, comparing deformations obtained from a numerical model and in situ measurements during the excavation of the open pit.
\end{abstract}

\section{Introduction}

In Kantrida, a part of the City of Rijeka, Croatia, the Water Sport Complex for the 2008 European Championship is under construction. The Complex includes a garage, a complex of three pools and a service building around the existing pool. The garage-enclosure in the north part of the sports complex was the most geotechnically demanding part of the construction because of the requirement for a deep open excavation. Several existing buildings (a petrol station and an apartment building) and a traffic line to the north closely surround the construction location. Geotechnical conditions on the site are very complex: on the lateral side limestone rock-mass outcrops at surface, while in the east-central part of the location there is a ravine filled with deep clayey deposits. The location has an inclined ravine shape, running in the direction SW-NE. The natural terrain surface was significantly changed by cut and fill activities. The elevations in the ravine ranges from 15.50 to $18.50 \mathrm{~m}$ above sea level (m a.s.1.), and the elevation of the traffic line above the construction site is $24.50 \mathrm{~m}$ above sea level. The designed footprint of the garage excavation encompasses dimensions of 75 by $20 \mathrm{~m}$ (Figure 1). The bottom of the pit was designed to be at $11.80 \mathrm{~m}$ a.s.1., and ranges from $14.50 \mathrm{~m}$ deep on the northern end of the location to $1 \mathrm{~m}$ depth on the southern end, adjacent to the existing buildings and traffic corridor. Due to complex ground conditions and sudden cover thickness variations in the southern part of the site, a static system of construction had to be adjusted according to the conditions encountered to ensure an acceptable building foundation. In order to design the excavation, its support system, and the building foundation, a detailed complex geotechnical investigation was performed. The open pit was constructed in several phases, using a retaining wall construction in the soil layers and reinforcement by rock bolts and a rigid reinforced system (reinforced concrete grid construction in the close vicinity of neighbouring buildings or multi-layered reinforced sprayed concrete elsewhere). During the open pit construction, a monitoring system was established. The monitoring system included deformeters and vertical inclinometers, and other observations like geodetic surveying and loading of the rockbolts. This provided the necessary data for a stress-strain back analysis of the response real behaviour of the excavated and reinforced 
rock mass. An active design procedure was established which made possible changes to the rock mass reinforcement system during the cuts. In this paper, we present the execution of the work, as well as the behaviour of the reinforcement systems, comparing deformations obtained from numerical modelling and in situ measurements during the excavation of the open pit for the garage enclosure for the Water Sport Complex Kantrida in Rijeka, Croatia.

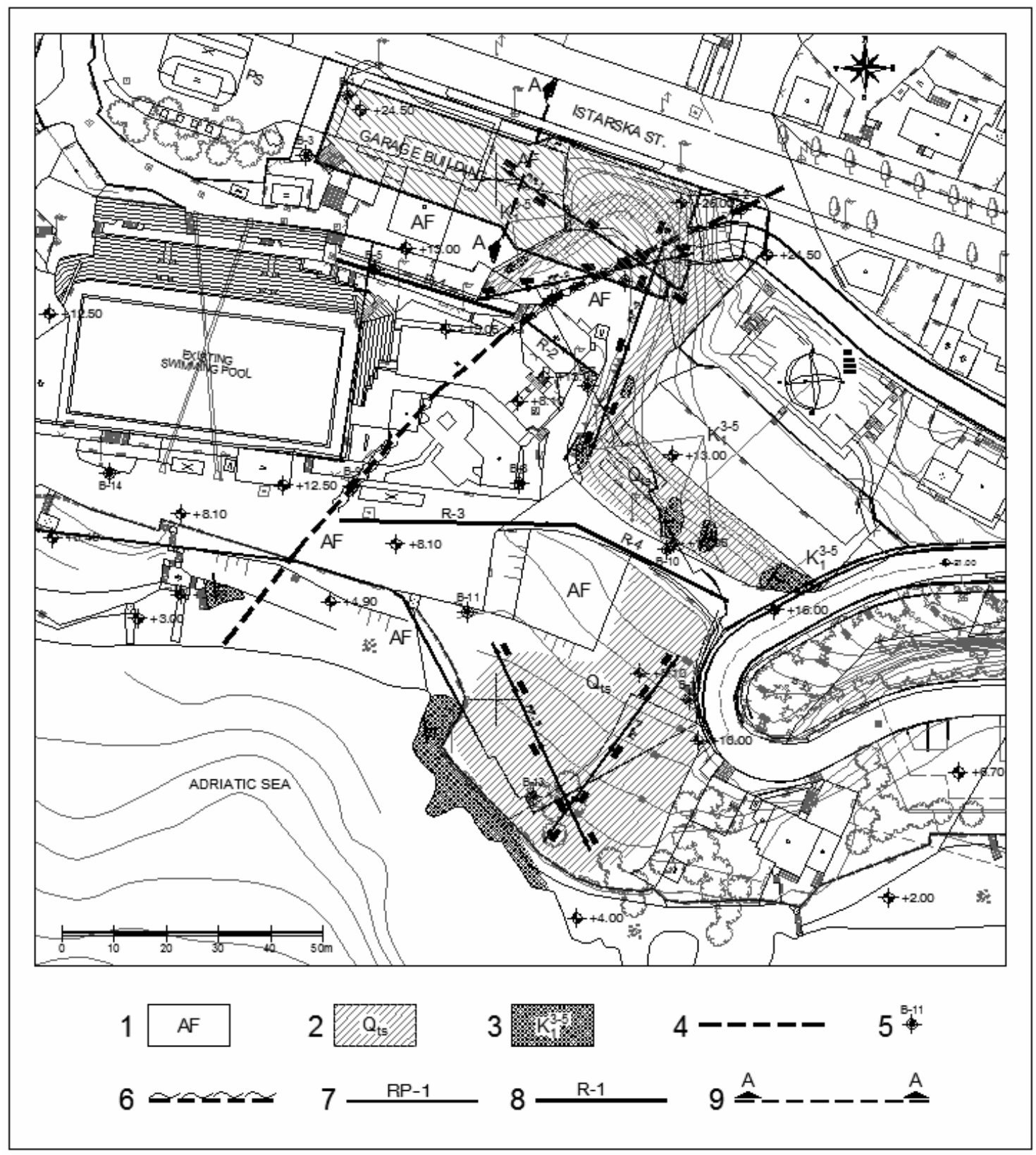

Figure 1 Engineering-geological map of Water Sport Complex Kantrida (1. AF-Fill; 2. $\mathrm{Q}_{\mathrm{ts}}$-Terra rosa; $3 . \mathrm{K}_{1}^{3-5}$-Exposed limestone outcrops; 4. Direction of the ravine; 5 . Borehole locations; 6. Extremly carstificated zone; 7. GPR profile; 8. Seismic refraction profile; 9. Crosssection A-A)

\section{Interactive design of the open pit excavation}

As a rule, the cutting of rock slopes occurs in civil engineering during the excavation of a building foundation, or in mining when extracting minerals and raw material, for which the only design parameter one can generally influence is the slope of the cut, resulting in the total height of the cut slope. For civil engineering applications, the time required to cut the slope is significantly shorter than the duration the cut 
must remain stable as part of the engineering construction. In mining, economical advantages can be gained in varying the geometry (slope angle) of the cut, whereas in civil engineering, the possible consequences of a slope failure necessitate a more conservative design. For example, in urban areas cuts are designed with very high safety factors, often by applying excessive support; in mining, slopes are sometimes designed with slope angles that often bring the risk of possible instability (Ross-Brown, 1972).

The cut slope inclination can be vertical or inclined, depending on conditions in the slope and conditions of the support construction that ensures the stability of the cut angle. This often depends on the relationship of the cost incurred if failure occurs and the construction cost of the retaining works. It is clear that in urban environments the price associated with potential damage claims significantly exceeds the price of ensuring the stability of the cut, which requires strict adherence to geometry with adequate reinforcement systems, compared to less conservative design geometries with minimal support. Therefore, design conditions in urban environments are frequently on the limit of practical realization and they demand extremely safe support systems that need to adhere to technical conditions of the designed works (Arbanas, 2002; Arbanas et al., 2003).

Designing rock mass cuts comes down to selecting an adequate geometry and/or necessary support systems. Based on the results of the geotechnical investigation and rock mass classification work carried out, strength parameters, rock mass deformability parameters can be defined, and a geotechnical model developed to perform a stability analysis. Stability analyses are carried out depending on the possible failure mechanism, using one of a number of established methods, whereby, as a result of the conducted analysis, the factor of safety is calculated. Most often stability analyses are performed that adopt limit state (limit equilibrium) methods using one of the many commercial software programs intended for this purpose. Stability analyses are carried out with the initial hypothesis that the rock mass, for a given cut geometry, stands unsupported in all excavation phases, for which initial safety factor values are derived. If the safety factor values calculated are deemed inadequate, the effects of using selected support systems are then included into the geotechnical model to ensure that the required safety factor is maintained throughout all phases of the construction works (Arbanas, 2002).

While selecting support structure systems one needs to take into consideration numerous conditions, including the behaviour of individual elements of the support structure (Windsor, 1992, 1996). Rock mass reinforcement by rockbolts, cable bolts or pre-stressed geotechnical anchors often form a constituent part of the support system. The contribution of a single rock mass reinforcement element is defined, as a rule, by its bearing capacity, and in order to calculate its impact on the factor of safety in a stability analysis, its element length and element grid are defined in the geotechnical model. By including reinforcement elements into the geotechnical model, and depending on possible failure mechanisms on the slope or cut, the position of a critical failure surface or even critical failure mechanism can be varied. By conducting stability analyses, a support structure is adopted, and it satisfies the wanted stability of the geotechnical model expressed by the wanted factor of safety.

Rockbolts, as rock mass reinforcement elements in the support structure, are frequently used today due to several advantages, as outlined by Stillborg (1994). Rockbolts may take various forms, from reinforcing bars of standard diameters used in civil engineering, to specially designed profiles manufactured according to their specific purpose. When using rockbolts, the main issue is how many rockbolts are required to properly reinforce the rock mass during cutting of the excavation. In the stability analysis, the benefits of the rockbolts, with respect to the cut's factor of safety, is calculated based on the bearing capacity of the rockbolts (assuming that the calculated force value is achieved).

This approach raises several questions as to its validity:

- The rockbolt capacity, as a rule, is based on data from the manufacturer's booklet for a given rockbolt or the steel used to manufacture it. These are largely based on laboratory pullout tests of the connection of individual elements or rockbolt head in the laboratory. Calculated force in the rockbolt is usually based on ultimate or yield force values. Based on recommendations, experience and application standards, usually the calculated or allowed force in the rockbolt are reduced by $20 \%$ compared to the ultimate force in the pullout tests. 


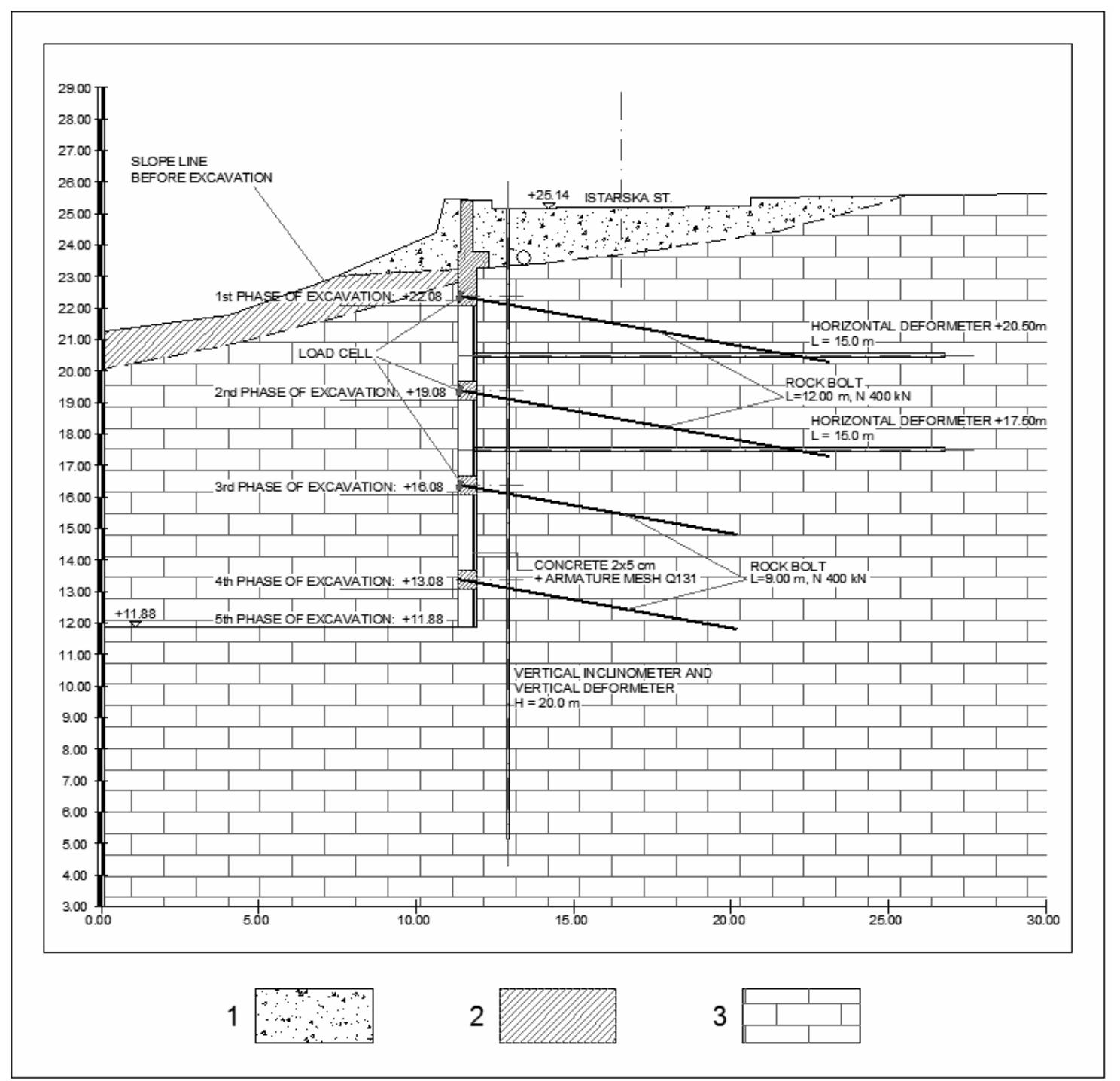

Figure 2 Control cross-section A-A of the cut "North" (1 - Fill; 2 - Terra rosa; 3 - Limestone)

- Practically speaking, rockbolts at the moment of installation do not represent a rock mass reinforcement element. To serve as a rock mass reinforcing element, a natural interaction must occur between the forces and displacements in the rock mass and those then induced in the support structure at the observed location (Windsor, 1996). The activation of the rockbolts is a consequence of rock mass displacements that are a consequence of rock mass relaxation after the installation of rockbolts and further deformation that happened during cutting. The amount of the forces activated in the rockbolts directly depends on the amount of deformation, which is not analysed as a rule in limit equilibrium stability analysis methods (Arbanas, 2002).

- By inserting the rockbolt calculated forces into the geotechnical models at the location of the outside connections of the reinforcement elements and the rock mass (Windsor and Thompson, 1996), the state of stress is significantly changed in the rock mass. Taking into consideration that the shear strength for a failure through the rock mass or a failure according to the established discontinuity directly depends on the strength of normal stress on the failure surface, it is obvious that normal stress on the possible slip surface unjustifiably increases by introducing rockbolt calculated forces, and as a consequence, rock material strength increases as well. Moreover, there is the problem of external load transfer from rock mass reinforcement elements (rockbolt) to the rock mass. It is clear that load transfer from the rockbolt to the rock mass will be ensured by constructing a stiffer support structure, inversely proportional to the rock mass cut quality that will be a part of the support structure. 
The above points suggest that the stability analysis approach adopted may result in safety factors that in reality may significantly differ because of an inaccurate hypothesis of the influence of rockbolts on the rock mass behaviour. Everything mentioned before indicates the need for a better understanding of rockbolt behaviour in certain areas of an excavation cut into which rockbolts, as rock mass reinforcement elements, are installed. This is achievable only by conducting stress-strain analyses during the design phase that give us information on possible rock mass strain during cutting, from which it is possible to estimate also what the contribution of rockbolts is to the overall rock cut stability. Stress-strain analyses provide displacement calculations along points where the rockbolts are installed, which enable calculated values of the activated forces in the rockbolts to be defined through estimated rockbolt stiffness values. Only based on the calculated strain and achieved forces in the rockbolts is it possible to conduct a cut stability analysis for a rock mass that can show a correct estimation of the safety factor. This points to the need of using stressstrain analyses and slope stability analyses in parallel, especially for deep excavations where it may be necessary to analyse the different stages of the excavation (together with the influence of the installation of rockbolts). Strain results determined through stress-strain analyses, according to excavation phases, will define the needed support and rock mass reinforcement systems, both with respect to installation geometry and bearing capacity. Rock mass reinforcing elements that meet the required safety factors will be used in a subsequent iteration of stress-strain analysis until the final required stability is achieved in the rockbolt reinforced rock mass.

An interactive rock mass excavation cut design, based on the observation method (Terzaghi and Peck, 1967; Peck, 1969; Powderham, 1998; Nicholson et al., 1999; Szavits-Nossan, 2006), was introduced in the phase of the construction. Rock mass cut design methodologies were shown by Hoek \& Bray (1977; see also Wyllie and Mah, 2004) and Hoek \& Brown (1980); and have been amended to include the selecting of support structures (Windsor and Thompson, 1992; Arbanas, 2002, 2004) and the appropriate rockbolts (Stillborg, 1994). With the proposed procedure, the need to re-design the cut and/or using additional support measures, could be enacted if during the excavation process a possible instability was detected or foreseen. If adequate support measures are proposed, then it still may be necessary to think about the possibility of modifications that would improve the stability state or optimize the design solution even further (Windsor and Thompson, 1992; Arbanas 2002, 2004). Stillborg (1994) indicates the need to supervise all parts of the project as a unique design process. It should be emphasized that the most important thing here is that the overall control of all activities, from investigation works, design, execution and monitoring, etc., is in the hands of one engineer, acting like designer and supervising engineer, because otherwise it is not possible to ensure adequate monitoring and the necessary rock mass reinforcement systems.

The second design phase, or the interactive design phase, comes down to the supervising of the constructing works during excavation and supporting the cut, as well as monitoring all the necessary activities that need to ensure safe execution of works within the required cut stability limits. Overall activity includes the carrying out of the supervising and monitoring as outlined in the design (Kovačević, 2003), as well as engineeringgeological mapping of the slope including rock mass classification and rock mass strength testing, during the excavation (Arbanas, 2002). Based on the above information, the following can be asserted said:

- Based on engineering-geological mapping data, the in-situ state of the rock mass can be established in the open cut much more precisely than during the geotechnical investigation works. Based on engineering-geological mapping, the possible failure mechanism in the cut can be confirmed, as well as rock mass classification elements.

- Data for carrying out the rock mass classification is completed based on intact rock strength estimations and characteristics of the discontinuity sets present (Bieniawski, 1989). Methods to define the unconfined rock strength include the Point Load Test (ISRM, 1981), by which intact rock strength values can be defined quickly and through more samples. Based on the rock mass classification carried out, the rock mass properties may be calculated using established empirical relationships (Hoek, 1994; Hoek and Brown, 1997; Hoek et al., 2002). The true rock mass properties however, may only be known with any certitude in cases where failure of the rock mass have actually occurred (Sjöberg, 1997, 1999; Sonmez et al., 1998). 


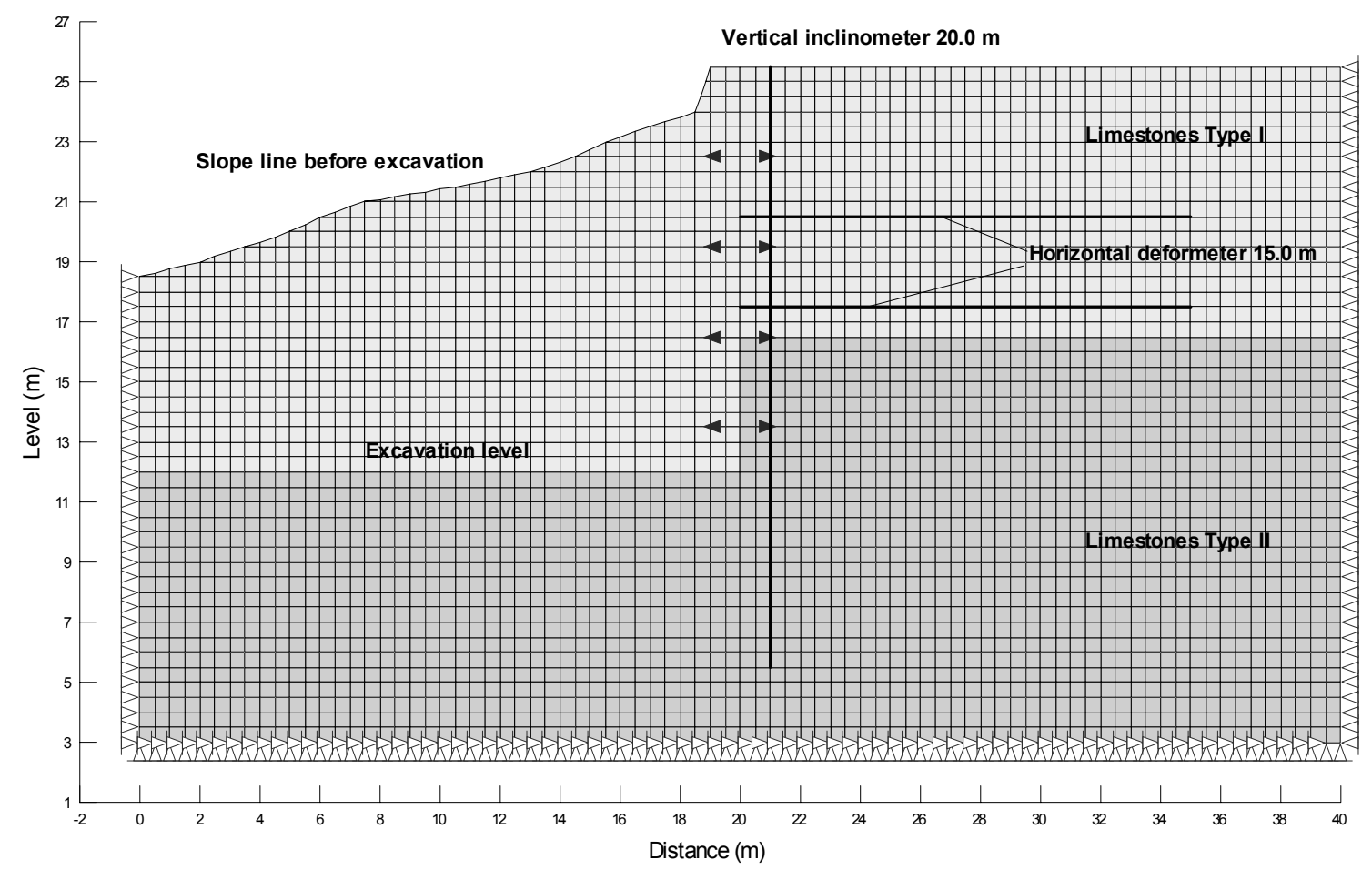

Figure 3 Finite element mesh for stress-strain analysis along cross-section A-A

- Acquisition of data that enables for the rock mass deformability moduli to be established may be based on geodetic measurements or displacements measured by inclinometers and extensometerdeformeters). This is possible when interactive design (observational method) is used (Arbanas et al., 2006a; Kovačević and Szavits-Nossan, 2006). One of the main elements of interactive design is monitoring during excavation and the construction of the support system, which includes surveying a net of benchmarks and measurement of rock mass displacements by inclinometers and extensometers-deformeters. When combined in the same vertical borehole (Amstad et al., 1988), the inclinometer component allows for the measurement of horizontal displacements along the borehole and the extensometer component (deformeters and sliding micrometer) is used for measuring the displacements along the borehole (e.g. see also Kovari et al., 1987). These measurements make it possible to determine with some accuracy the values of the deformation modulus of the rock mass through back analysis of its stress-strain behaviour in which measured and calculated displacements are matched to the level of engineering accuracy deemed acceptable (Arbanas, 2002, 2003, 2004; Arbanas et al., 2003, 2004, 2005, 2006; Kovačević and Szavits-Nossan, 2006; Szavits-Nossan et al., 2006). Rock mass deformability modules, as it has already been described, can be estimated in other ways as well, for example, in correlation with rock mass classifications (Bieniawski, 1989; Serafim and Pereira, 1983; Hoek et al., 2002; Arbanas et al., 2005). However, these estimations in some cases may be too generalized, for example when derived from a limited data base covering a wide area of different rock mass types and wide range of different rock mass behaviours. Empirical values based on rock mass classification values cannot compete with measured values taken from the monitored location.

- Based on pull-out rockbolt testing results (ISRM, 1981), stiffness of the installed rockbolts is defined in the area of the design rockbolt work force. In combination with measured displacements, it is possible to define an acting force in the rockbolt for certain stages of excavation of the rock mass cut. A more reliable method would involve installing load cells with the rockbolt (Farmer, 1975) or using extensometer data from one installed immediately next to the rockbolt (Thompson et al., 1995); however it is rarely used in practice because of its cost. 


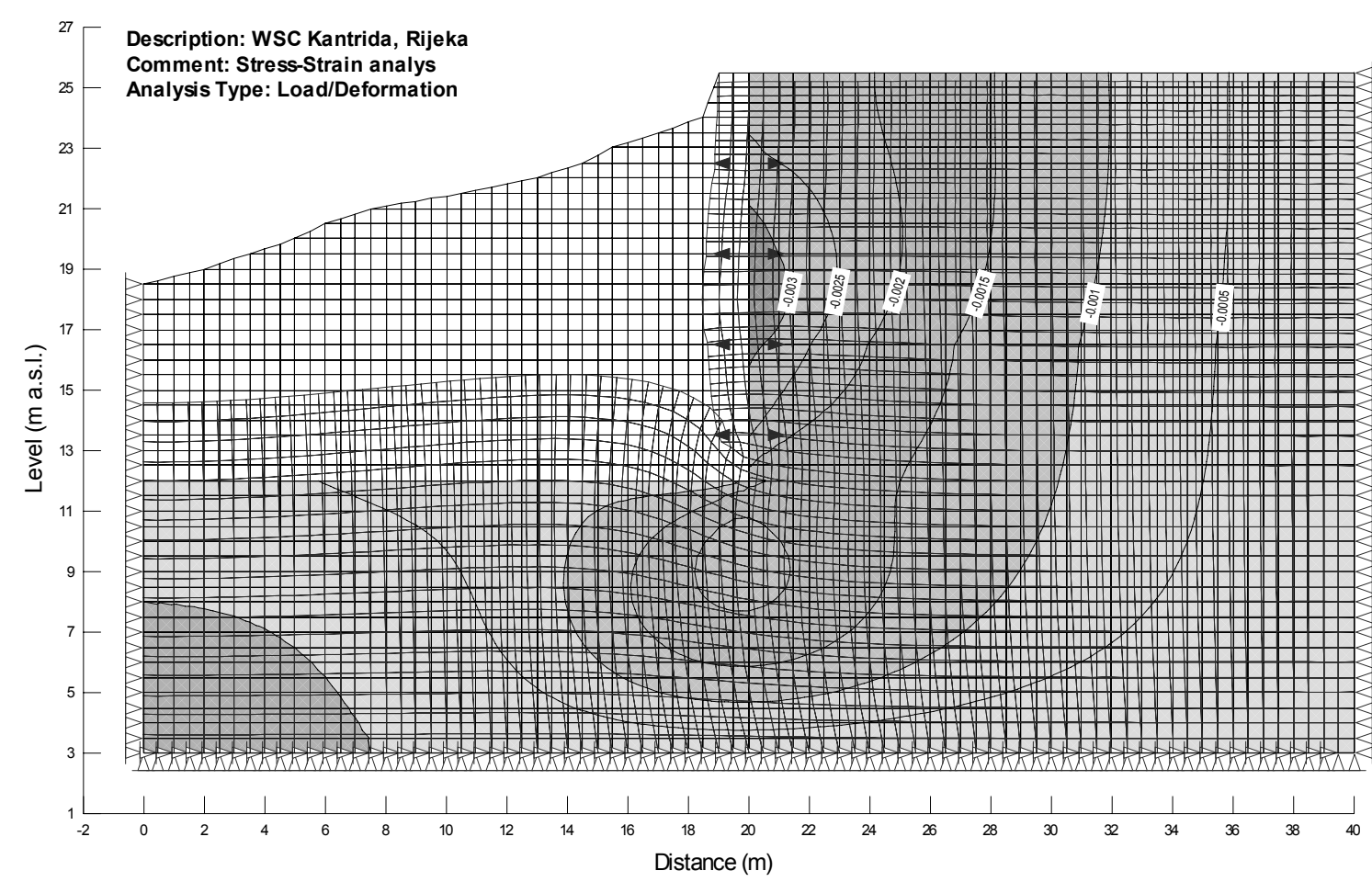

Figure 4 Deformed finite element mesh and isolines of horizontal displacements from stress-strain analysis on cross-section A-A

These estimations enable a back analysis of the rock mass behaviour. The stress-strain back analysis, together with adopted rock mass strength parameters based on the rock mass classification and measured displacements, are then used to establish the rock mass deformability moduli. Based on measured displacements and established stiffness of the installed rockbolts, the values of activated forces in the installed rockbolts are defined. The defined force values in the rockbolts are then used in the cut stability analyses, carried out analysis, using one of the limit state analyses methods. The result of the analysis provides a closer representation of the true stability state of the rock cut, reinforced by rockbolts, expressed in terms of the factor of safety. This procedure has to follow the cut excavation stages in the rock mass (Arbanas, 2002).

Current practice does not always follow the previously suggested procedure of combining limit equilibrium and numerical approaches in the second design phase during the rock mass cutting. Geotechnical design, following the methodology described, better establishes the stability state of the cut as a function of the calculated values of the forces in rockbolts used in the stability analysis. Stress-strain analyses are mostly used in defining limit values of the allowed rock mass deformations in a rock cut, in the first design phase; while back stress-strain analyses following the first excavation stage are rarely carried out except in cases involving unpredicted situations or a failure in the slope (Sonmez et al., 1998). Stress-strain back analyses are conducted in some cases, but these are still missing the use monitoring data of force values from installed rockbolts to constrain the analyses (Arbanas et al., 2005; Arbanas et al., 2006a) and add confidence to the stability prediction of the rock cut so as real cut stability expressed by factor of safety.

A confirmation of the above mentioned opinions will be shown through the working design of the rock cut on the garage excavation for the Water Sport Complex Kantrida in the town of Rijeka.

\section{Geotechnical properties of the Water Sport Complex Kantrida location}

For the needs of establishing the geological content of the soil on the pit excavation site, complex geotechnical investigation works were carried out. Investigation works consisted of borings, geophysical surveys (seismic surface refraction and ground probing radar), laboratory testing of soil and rock mass samples, and engineering-geological mapping of the site and geotechnical prospecting of the location. 
Sixteen investigation boreholes, five seismic refraction profiles and four ground probing radar profiles were completed in total (Figure 1).

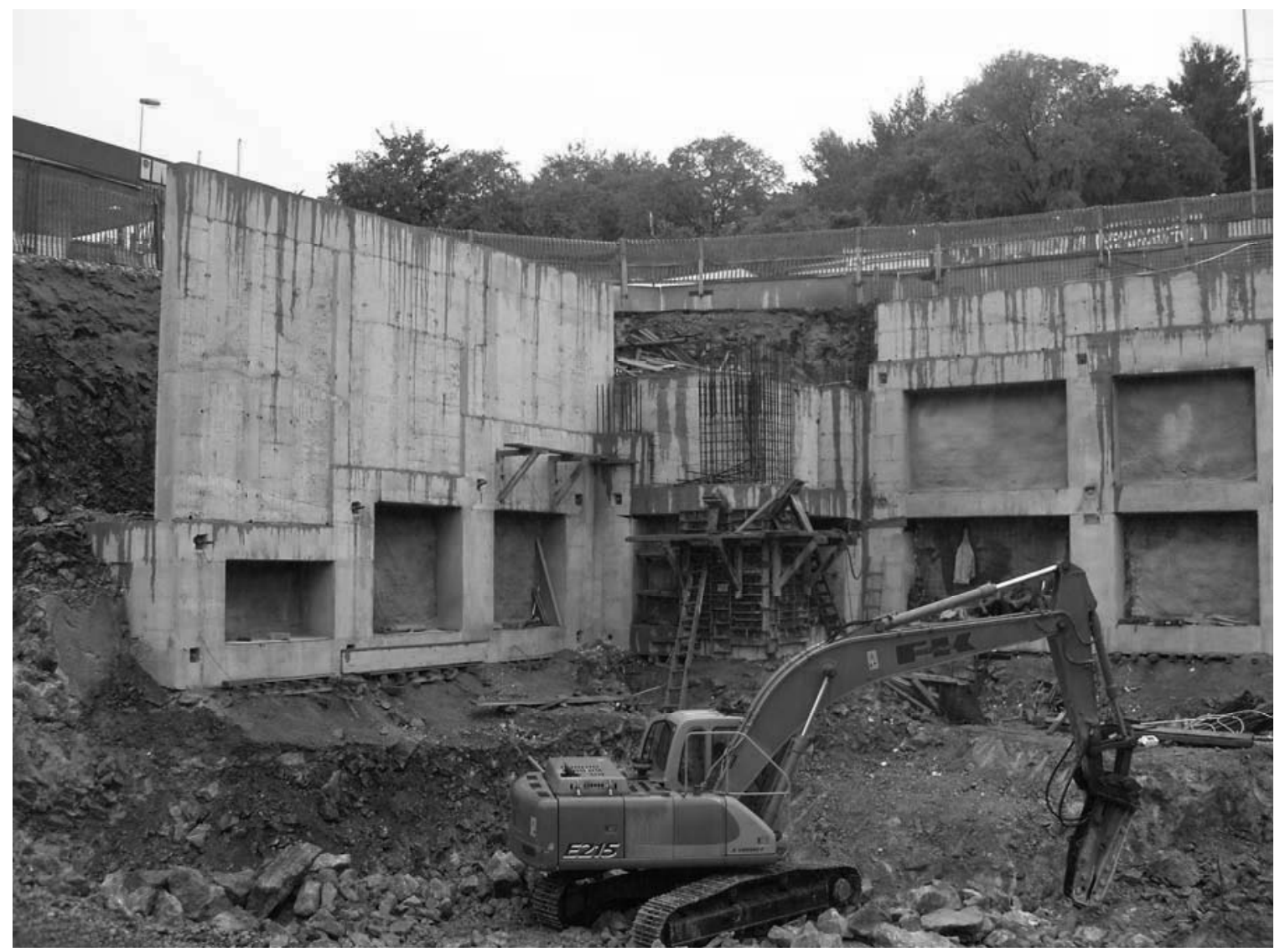

Figure 5 Reinforced concrete support construction during construction of open pit (photo courtesy Ž. Arbanas, September 2006)

During the site investigation, the location was partially built on, covered with fill, with only a small section retaining its autochthonous appearance. Because of cutting and filling during construction, the terrain has a terrace-like appearance. Bedrock outcrops were visible only occasionally on the surface. The larger part of the site was covered by fill, and in places, with terra rossa (residual soils from weathered limestones). Investigation works defined the boundary between the cover deposits and the bedrock. The cover consists of a heterogenic fill, spread as a non-continuous discontinulayer of varying thickness, together with autochthonous clay cover - terra rossa. The fill is made up of a mixture of stone fragments and clay in different ratios, with waste building material. Terra rossa was found as a thin continuous cover above the rock base or between outcrops of bedrock on surface. It is inorganic, silty clay, of a red or reddish-brown colour, medium to high plasticity and of very stiff consistency. The cover is $1.50 \mathrm{~m}$ thick, except in the ravine in the eastern part of the location, where it reaches more than $10 \mathrm{~m}$.

The base consists of limestone and limestone breccia. The limestone ranges from a microcrystal to macrocrystal structure, of a dark-grey to dark-brown colour. Limestone and breccia are both stratified and not stratified, as well as forming blocks, with strata depths from 0.20 to $1.00 \mathrm{~m}$. The strata are generally sloping towards the southeast at an angle of $35^{\circ}$ to $70^{\circ}$. Basic tectonic construction is defined by the stratifying position. On the surface, where bedrock is in contact with the cover, it is more intensely cracked and damaged. The measured Rock Quality Designation index, RQD, was from $0 \%$ to $75 \%$. The rock is mostly medium to weekly carstificated, except in surface and tectonically crushed zones (along the ravine fault). According to the geotechnical investigation results, the bedrock could be divided in two types:

- Type I - completely weathered, fissured and carstificated bedrock; consisting of either rock fragments in the clay mass, or of a very cracked rock with a discontinuity gap in all three main directions; around $6 \mathrm{~cm}$, with the longitudinal seismic wave velocity under $2400 \mathrm{~m} / \mathrm{s}$ and RQD 
$<10 \%$. The geomechanical classification established was RMR $=36$ (Bieniawski, 1989), or GSI = 31 (Marinos and Hoek, 2000; Marinos et al., 2005).

- $\quad$ Type II - carstificated and fissured bedrock; with a discontinuity gap or rock block size between 6 and $20 \mathrm{~cm}$, and the longitudinal seismic wave velocity between 2400 and $3200 \mathrm{~m} / \mathrm{s}$ and RQD between 10 and $75 \%$; the geomechanical classification established was RMR $=47$, or GSI $=42$.

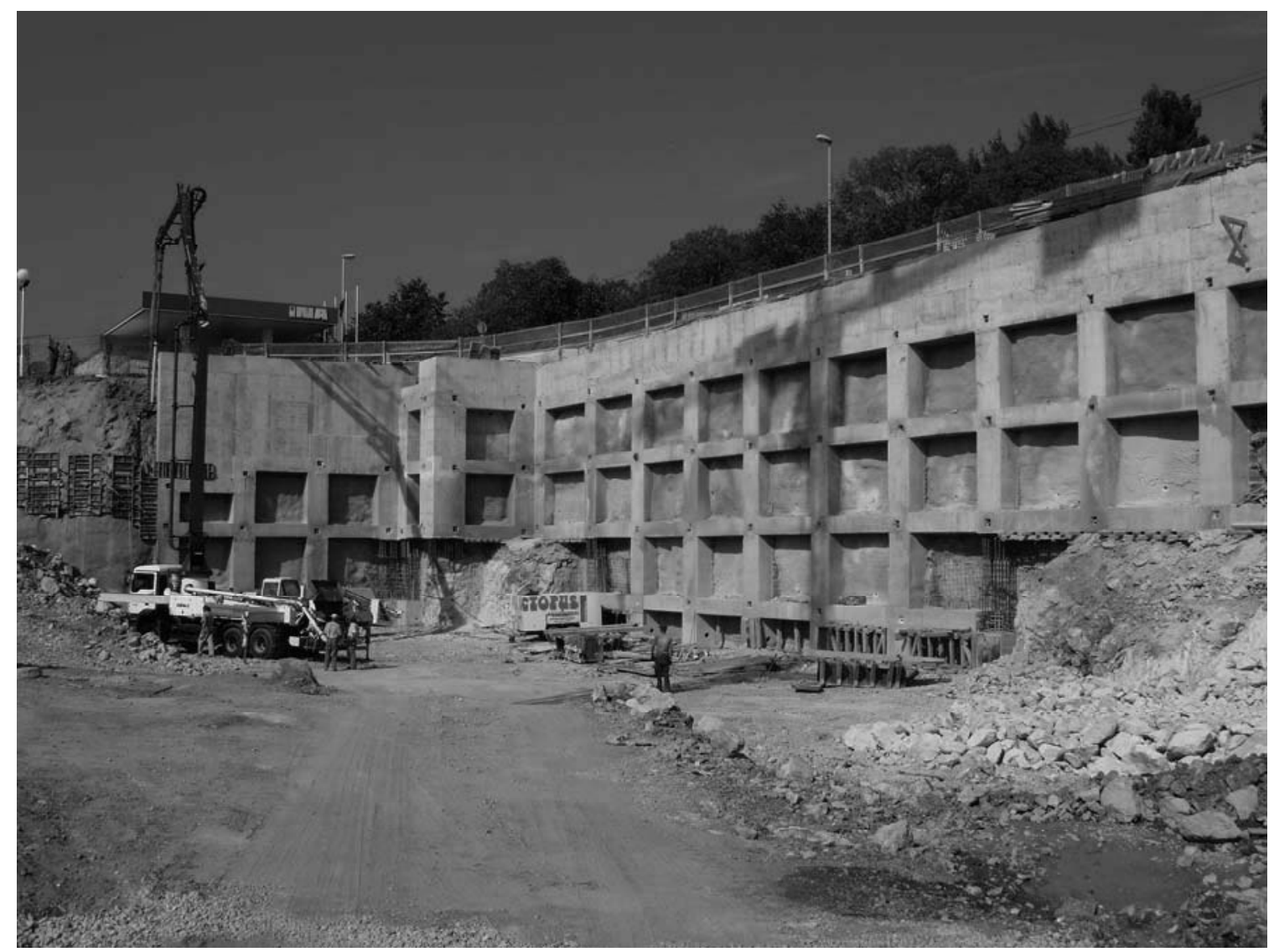

Figure 6 Reinforced concrete support construction during construction of open pit (photo Ž. Arbanas, October 2006)

\section{Rock mass reinforcing system}

Based on the results of the geotechnical investigations, a project was designed to secure the walls of the construction pit. A selection of the support structure and rock mass reinforcement was based on stability analysis results for a possible failure in the rock mass using the program package GEO-Slope Slope/W (GEO-Slope, 1998) for a circular slip surface. In addition, stress-strain state analyses were carried out to analyse the bedrock displacements and the activation of the rockbolt forces (Figures 2,3). A combination of these analyses confirmed the need for rock mass reinforcement (Figure 4).

The construction of a reinforced concrete grid was selected as a suitable support system, with self drilled rockbolts in grid knots (Figure 2). On the surface, in the cover strata, the construction of L-retaining walls was called for, leaning against the grid reinforced concrete construction. Based on a construction design that ensured stability of the construction pit, the construction methodology enabled the pit to be excavated in stages from the top towards the bottom of the open pit, Figure 5.

Geodetic observations, as well as measurements of displacements on inclinometers and extensometers, were performed in phases, according to the staged phases of excavation. The execution of works on the "North" cut, as the most complicated open pit geotechnical construction, were performed in longitudinal cuts of $3 \mathrm{~m}$ height together with a successive construction of a concrete mesh support system reinforced by selfboring rock bolts from top to bottom of the excavation (Figures 1 and 2). 


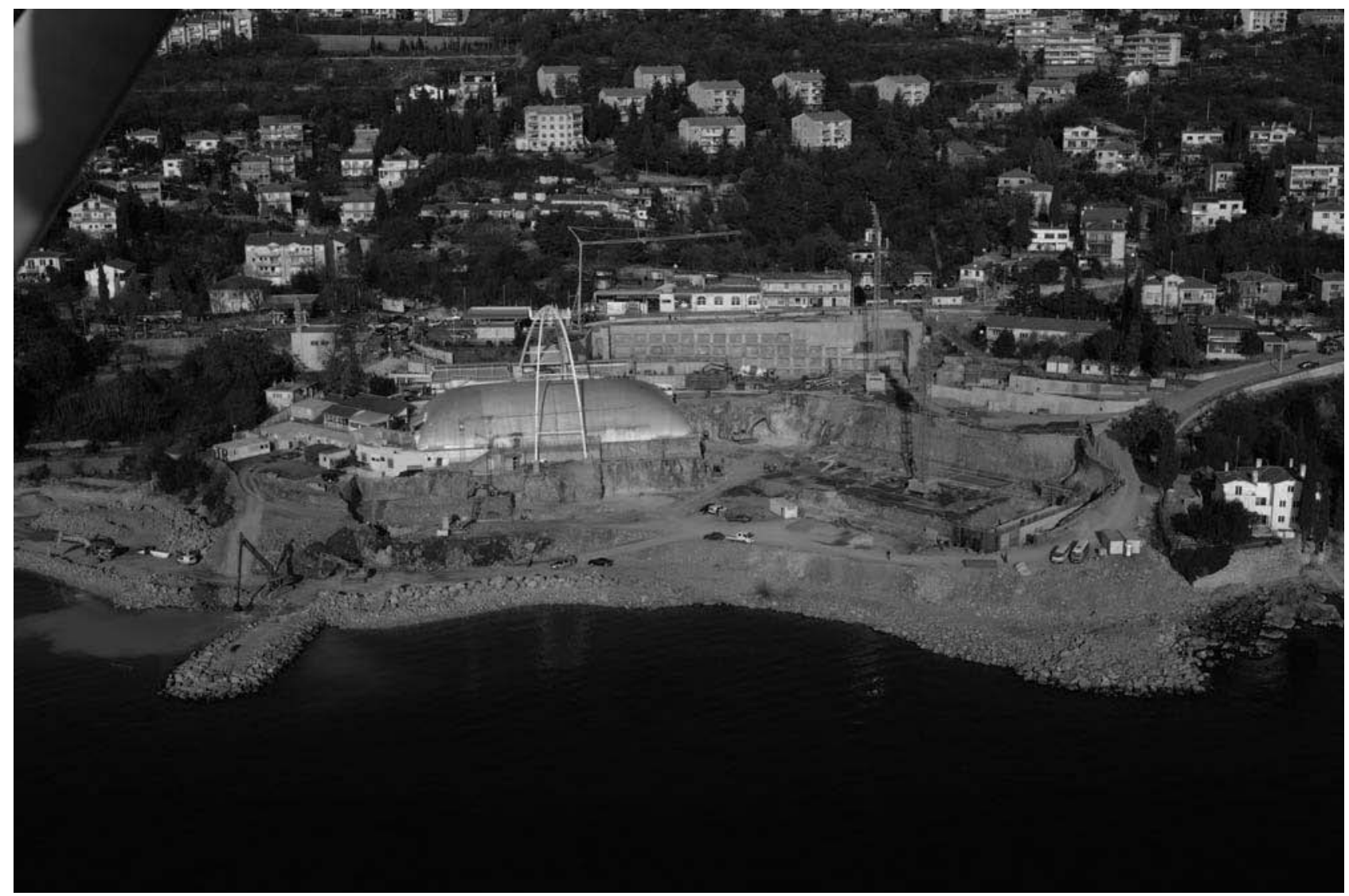

Figure 7 Aera photo of the site during work execution (photo D. Frka, December 2006)

Grid construction was constructed with a $4.0 \mathrm{~m}$ horizontal column spacing interval and a $3 \mathrm{~m}$ vertical beam interval, while $12 \mathrm{~m}$ and $9 \mathrm{~m}$ long rockbolts, with a $400 \mathrm{kN}$ bearing capacity were installed into the construction knots (Figures 2, 5, 6 and 7). Stress-strain back analysis, based on the measured deformations, and performed bearing capacity tests of the rockbolts enabled observation and prediction of the rock mass behaviour for future phases of the excavation. Bedrock strain characteristics derived from the stress-strain back analyses were adopted based on experience acquired working with limestone rocks of similar characteristics (Arbanas et al., 2003, 2004). Deformation characteristics of the limestone rock mass are significantly lower than the values derived from correlation with bedrock classifications (Hoek et al., 2002).

Measuring strain in the horizontal extensometers (deformeters) also enabled the force distribution along the rockbolts to be determined. Horizontal extensometers (deformeters) were installed in the immediate proximity of rockbolts, and the measured strain showed the elongation of the rockbolt due to rock deformation. This gives data on the activated force and force distribution along the rockbolt. These data enabled the actual force values in the rockbolts to be used to constrain limit equilibrium back analyses of stability and safety factors for the cut and the stress-strain back analyses (Arbanas, 2002; Arbanas et al., 2006a).

The results of measured deformations on the control measuring cross-section 2-2 (Figure 2) on the cut "North" are shown in Figure 8. Measured strain in the vertical inclinometers-extensometers (deformeters) and horizontal extensometers (deformeters) showed a good match with the predicted calculated strain for all excavation stages. Because of this, rock mass reinforcement works were carried out according to the design solution with minimal changes (Figure 9). 


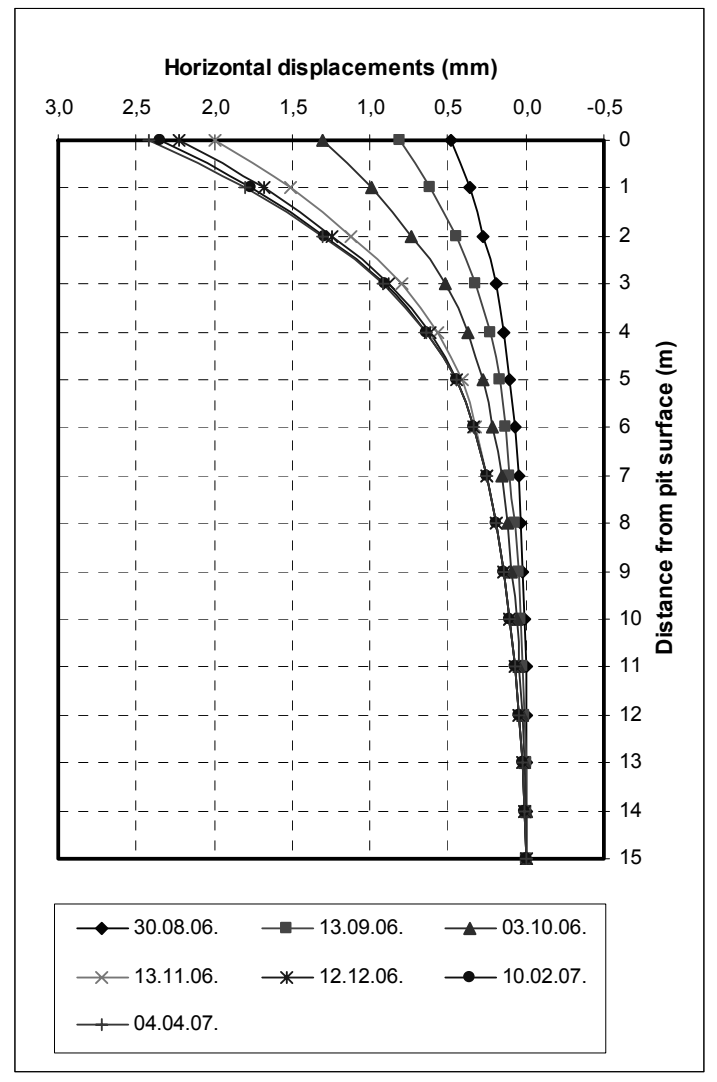

a)

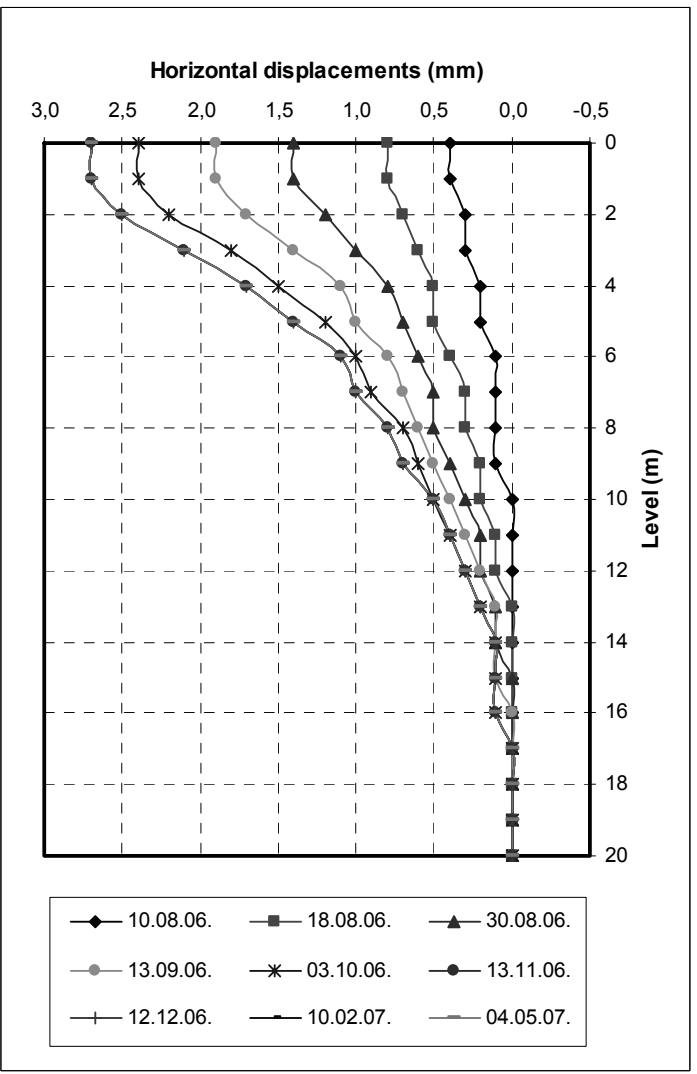

b)

Figure 8 Measured horizontal deformation on cross-section A-A during work execution in upper horizontal deformeter (a) and vertical inclinometer (b)

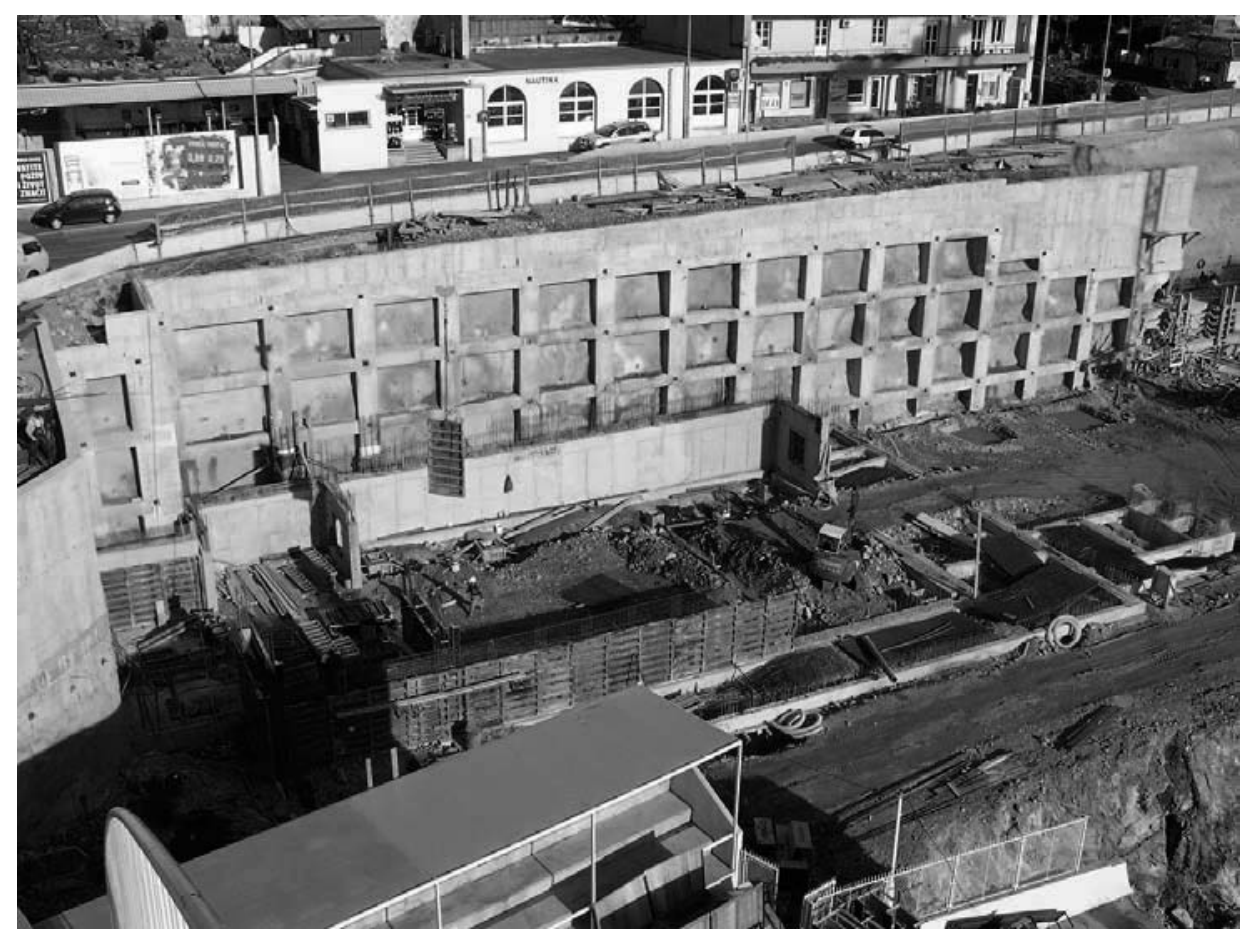

Figure 9 Photo of reinforced grid support structure on cut "North" (photo T. Pap, December 2006) 


\section{Conclusion}

Excavation of an open pit for the construction of a garage in the Kantrida part of the City of Rijeka, Croatia, proved to be the most geotechnical demanding part of construction works for the Water Sport Complex for the 2008 European Championships. The geotechnical conditions encountered on site were: limestone outcrops, cut in the eastern-central part of the location by a ravine filled with deep clayey deposits. The open pit was constructed in several stages, with a retaining construction in the soil layers and rock mass reinforcement by rockbolts and a stiff reinforced system: grid construction and multi-layered reinforced sprayed concrete. An active design procedure was established, which made possible changes required in the rock mass reinforcement system during excavation of the cuts. Stress-strain back analysis, based on the measured deformations, and performed pull-out bearing capacity tests of rockbolts, enabled observation and the prediction of rock mass behaviour in the cuts to be applied to future phases of excavation. Measured strain on vertical inclinometers-extensometers (deformeters) and horizontal extensometers (deformeters) showed a good match with the predicted calculated strain in all stages of works. Because of this, rock mass reinforcement works were carried out according to the preliminary design with minimal changes.

\section{References}

Arbanas, Ž. (2002) The influence of rockbolts on the rock mass behaviour during excavation of deep cuts, MSc Thesis, Faculty of Civil Engineering, University of Zagreb (in Croatian), 207 p.

Arbanas, Ž. (2003) Construction of open pit Zagrad in Rijeka, Građevinar, Vol. 55, No. 10, pp. $591-597$ (in Croatian).

Arbanas, Ž. (2004) Prediction of supported rock mass behaviour by analysing results of monitoring of constructed structures, PhD Thesis, Faculty of Civil Engineering, University of Zagreb (in Croatian), 220 p.

Arbanas, Ž., Grošić, M. and Jurić-Kaćunić, D. (2006a) Influence of grouting and grouting mass properties on reinforced rock mass behaviour. Proceedings 4th Conference of the Croatian Geotechnical Society, Soil and Rock Improvement, Opatija, V. Szavits-Nossan and M.S. Kovačević (eds), Croatian Geotech. Society, Zagreb, 5-7 October, pp. 55-64 (in Croatian).

Arbanas, Ž., Jardas, B. and Kovačević, M.-S. (2003) Reinforcement Systems in Construction of Open Pit Zagrad in Rijeka, Croatia. Proceedings 13th European Conference on Soil Mechanics and Geotechnical Engineering, Geotechnical Problems with Man-made and Man Influenced Grounds, Prague, Czech Republik, I. Vaniček, R. Barvinek, J. Bohač, J. Jettmar, D. Jirasko and J. Salak (eds), August 25-28, Vol. 2, pp. 23-28.

Arbanas, Ž., Jardas, B. and Kovačević, M.-S. (2004) Excavation of Open Pit Zagrad in Rijeka, Croatia-A case history. Proceedings 5th International Conference on Case Histories in Geotechnical Engineering, New York, NY, USA, April 13-17, pp. 5.64.1-5.64.6.

Arbanas, Ž., Kovačević, M.-S., Grošić, M. and Jardas, B. (2005) Some Experience During Open Pit Excavation in Limestone Rock Mass. Proceeding from the. International Conference EUROCK 2005, Impact of Human Activity on the Geological Environment, P. Konečny (editor), Brno, Czech Republik, May 18-20, A.A. Balkema, Taylor \& Francis Group, London, pp. 31-36.

Arbanas, Ž., Kovačević, M.-S. and Szavits-Nossan, V. (2006) Interactive design for deep excavations. Proceeding of XIII Danube-European Conference on Geotechnical Engineering, Active Geotechnical Design in Infrastructure Development, J. Logar, A. Gaberc and B. Majes (eds), Slovenian Geotechnical Society, Ljubljana, May 29-31, Vol. 2, pp. 411-416.

Amstad, C., Kovari, K. and Koeppel, J. (1988) TRIVEC - Measurement in Geotechnical Engineering. 2nd International Symposium on Field Measurements in Geotechnics, Sakurai (editor), Balkema, Rotterdam, pp. 17-32.

Bieniawski, Z.T. (1989) Engineering Rock Mass Classification, John Wiley \& Sons, New York, 251 p.

Farmer, I.W. (1975) Stress Distribution along a Resin Grouted Rock Anchor, Int. J. Rock Mech. \& Mining Sci. \& Geomechanics Abstracts, Vol. 12, pp. 347-351.

GEO-Slope Int. Ltd. (1998) User's Guide Slope/W for Slope Stability Analysis, Version 4, Calgary.

Hoek, E. (1994) Strength of Rock and Rock Masses, ISRM News Journal, Vol. 2, (2), pp. 4-16.

Hoek, E. and Bray, J.W. (1977) Rock Slope Engineering, 2nd edition, The Institute of Mining and Metallurgy, London, $527 \mathrm{p}$.

Hoek, E. and Brown, E.T. (1980) Empirical Strength Criterion for Rock Masses, Jour. Geotech. Engng. Div., ASCE 106, (GT9), pp. 1013-1035.

Hoek, E. and Brown, E.T. (1997) Practical Estimates of Rock Strength, Int. J. Rock Mech. \& Mining Sci. \& Geomechanics Abstracts, Vol. 34 (8), pp. 1165-1187.

Hoek, E., Carranza-Torres, C.T. and Corkum, B. (2002) Hoek-Brown Failure Criterion-2002 Edition, Proceedings 5th North American Rock Mechanics Symposium, Toronto, Canada, Dept. Civ. Engineering, University of Toronto, pp. 267-273. 
ISRM, Commission on Standardization of Laboratory and Field Test (1981) ISRM Suggested Methods for Rockbolt Testing, Pergamon Press, Oxford, pp. 161-168.

Kovačević, M.-S. (2003) The Observational Method and the Use of Geotechnical Measurements. Geotechnical problems with man-made and man influenced grounds, Proc. 13th European. Conference on Soil Mechanics and Geotechnical Engineering, Prague, Czech Republic, August 25-28, Vol. 3, pp. 575-582.

Kovačević, M.-S. and Szavits-Nossan, V. (2006) Interactive design - Croatian experience, Proceeding of XIII DanubeEuropean Conference on Geotechnical Engineering, Active Geotechnical Design in Infrastructure Development, J. Logar, A. Gaberc and B. Majes (editors), Slovenian Geotechnical Society, Ljubljana, May 29-31, Vol. 2, pp. 451-455.

Kovari, K. Amstad, C. and Koeppel, J. (1987) Field Investigation of Disturbed Zones around Excavations by Strain Distribution Measurements, Coupled Processes Associated with Nuclear Waste Respositories, Academic Press, pp. 633-672.

Marinos, P. and Hoek, E. (2000) GSI: A geologically friendly tool for rock mass strength estimation. Proceedings GeoEng 2000 at the international conference on geotechnical and geological engineering, Melbourne, Technomic publishers, Lancaster, pp. 1422-1446.

Marinos, V., Marinos, P. and Hoek, E. (2005) The geological strength index: applications and limitations, Bull Eng Geol Environ (2005) 64, pp. 55-65.

Nicholson, D.P., Tse, C.M. and Penny, C. (1999) The Observational Method in Ground Engineering: Principles and Applications, Report 185, CIRIA, London.

Peck, R.B. (1969) Advantages and limitations of the observational method in applied soil mechanics, Géotechnique, Vol. 19 (2), pp. 171-187.

Powderham, A.J. (1998) The observational method-application through progressive modification. Civil Engineering Practice, Journal of the Boston Society of Civil Engineers Section/ASCE, Vol. 13 (2), pp. 87-110.

Ross-Brown, D.M. (1972) Design Considerations for Excavated Mine Slopes in Hard Rock, Research Report No. 21, Departments of Civil Engineering, Geology and Mining and Mineral Technology, Imperial College of Science and Technology, London, $21 \mathrm{p}$.

Serafim, J.L. and Pereira, J.P. (1983) Consideration of the Geomechanical Classification of Bieniawski. Proc. Int. Symp. on Engineering Geology and Underground Construction, Lisbon, Vol. 1, pp. II.33-II.42.

Sjöberg, J. (1997) Estimating Rock Mass Strength Using the Hoek - Brown Failure Criterion and Rock Mass Classification - A Review and Application to the Aznarcollar Open Pit, Internal Report BM1997:02, Lulea University of Technology, $61 \mathrm{p}$.

Sjöberg, J. (1999) Analysis of Large Scale Rock Slope, PhD Thesis, Lulea University of Technology, Lulea, Sweden, $788 \mathrm{p}$.

Sonmez, H., Ulusay, R. and Gokceoglu, C. (1998) A Practical Procedure for the Back Analysis of Slope Failures in Closely Jointed Rock, Int. J. Rock Mech. Min. Sci., Vol. 35, No.2., pp. 219 - 233.

Stillborg, B. (1994) Professional Users Handbook for Rock Bolting, Trans Tech Publications, Series on Rock and Soil Mechanics, Vol. 18, 2nd edition, Clausthal-Zellerfeld, 164 p.

Szavits-Nossan, A. (2006) Observations on the observational Methods, Proceeding of XIII Danube-European Conference on Geotechnical Engineering, Active Geotechnical Design in Infrastructure Development, J. Logar, A. Gaberc and B. Majes (eds), Slovenian Geotechnical Society, Ljubljana, May 29-31, Vol. 1, pp.171-178.

Szavits-Nossan, A, Kovačević, M.-S. and Szavits-Nossan, V. (2006) Observational Method and Croatian Experience, Proc. 4th. Conf. of the Croatian Geotechnical Society, Soil and Rock Improvement, Opatija, V. Szavits-Nossan and M.S. Kovačević (eds), Croatian Geotech. Society, Zagreb, 5-7 October, pp. 259-268, (in Croatian).

Terzaghi, K. and Peck, R. B. (1967) Soil Mechanics in Engineering Practice. John Wiley, New York.

Thompson, A.G., Windsor, C.R., Robertson, W.V. and Robertson, I.G. (1995) Case Study of an Instrumented Reinforcement Pit Slope, Proceeding $35^{\text {th }}$ US Symposium on Rock Mechanics, Lake Tahoe, A.A. Balkema, Rotterdam, pp. 381-386.

Windsor, C.R. (1992) Block Stability in Jointed Rock Masses, Fractured and Jointed Rock Masses, Proceeding of International Conference on Fractured and Jointed Rock Masses, L.R. Myer, N.G.W. Cook, R.E. Goodman, and. C.F. Tsang (eds), Lake Tahoe, A. A. Balkema, Rotterdam, pp. 59-66.

Windsor, C.R. (1996) Rock Reinforcement Systems, 1996 Schlumberger Award - Special Lecture, Proceeding of EUROCK '96, Special Papers Volume, Torino, Italy, http://www.roctec.com.au/papers.html.

Windsor, C.R. and Thompson, A.G. (1992) Reinforcement Design for Jointed Rock Masses, Proceeding $33^{\text {rd }}$ US Symposium on Rock Mechanics, Santa Fe, Rock Mechanics, Tillerson and Wawersik (eds), A. A. Balkema, Rotterdam, pp. 521-530.

Windsor, C.R. and Thompson, A.G. (1996) Terminology in Rock Reinforced Practice, Proc. $2^{\text {nd }}$ North American Rock Mechanics Conference NARMS'96 - Tools and Techniques, Montreal, M. Aubertin, F. Hassani and H. Mitri (eds), V1, A. A. Balkema, Rotterdam, pp. $225-232$.

Wyllie, D.C. and Mah, C.W. (2004) Rock Slope Engineering, Civil and Mining, 4th edtion, Spon Press, New York, Taylor \& Francis Group, 431 p. 